\title{
WORK IN MULTICULTURAL ENVIRONMENT
}

\author{
Stanislava Stoyanova \\ South-West University "Neofit Rilski", Bulgaria \\ E-mail: avka@abv.bg
}

Many people meet the differences of national cultures not only as tourists but also in their everyday working life, because the fast process of migration, internationalisation and globalisation inevitably integrate cultures within the framework of multinational organizations (Konečná, 2006).

Multicultural environment means diversity in terms of ethnicity, gender, religious, social belonging, etc. Multicultural environment retains workers from a variety of cultural backgrounds. The work is such environment differs in the various approaches to time, information, planning, decisionmaking, relationships, communication style, power, resolving conflict, developing leadership and motivation (CHARIS, 2012).

Organizations and cultures whose values are weak uncertainty avoidance, femininity, and low power distance strive for maximizing the benefits of diversity - like in the case of Scandinavian countries for example (Hofstede, 2001). The knowledge of cultural differences may help the workers operating in multicultural environment to reduce the possible misunderstandings and it enables them to foresee the possible reactions of their partners (Konečná, 2006). Work in multicultural teams requires flexibility, adaptation, understanding and respect for different cultures and values, tolerance, open-mindedness, friendly communication and good non-verbal communication skills.

The employees who strive to demonstrate only acceptable in the organization emotions would probably suffer from harmful consequences related to their health, relations, and work performance, including burn-out. The correspondence between the experienced and demonstrated emotions is not related to such harmful consequences (Mesmer-Magnus, DeChurch \& Wax, 2012).

Environment that constantly changes provokes stress and tension (Petrov, 2006). The requirements of the work (tension, physical exhaustion) are the main risk factors for burn-out (emotional exhaustion, depersonalization, and less successful coping, less personal realization) (Recchia \& Steffgen, 2007).

There are different educational methods and approaches for work in intercultural environment. The interactive methods are used, as well as discussion, the methods of the concrete situation - casus, role-playing games, games for intercultural competence; games for introduction, cooperations, etc. Their goal is increase of tolerance, intercultural sensitivity and intercultural communicative competence (Totzeva, 2012).

Communicative competence in multicultural environment includes the proper use of verbal and non-verbal expressive linguistic messages - appellative (strive for impact on the others), informative, evaluative, and self-revealing ones. The implicit appeals in the process of communication are expressed in an indirect way by means of establishment of such emotional climate that makes the other people execute the untold wish - for example, if someone looks sad, we strive to make him/ her glad. The paradoxical appeals in the process of communication aim to provoke the opposite reactions to these that they announce as aiming to provoke. For example, if a child in the kindergarten does not want to eat, this child is told that the food is not for him/her and s/he must not eat it. The explicit appeals are avoided because of fear of self-revelation, fear of denial, fear of limiting the other's freedom, reluctance to take responsibility (Mizova, 2004). 
Work in multicultural environment has different aspects from the points of view of the organizations, managers, employees, and their families.

The boys till $5^{\text {th }}$ grade in Korea, Japan, and USA are more interested in the numbers and in the objects than the girls who are more interested in the words (Henderson, Marx \& Kim, 1999). The boys are more competitive than the girls are in the Anglo-American, Indian and Mexican cultures, but the opposite trend is found for Israeli children (Strube, 1981).

The children raised in the institutions do not trust the world in the unknown and unsure situations. They do not take the initiative in the play. Their play misses the organizational part related to role distribution, planning, and plot development. They strive for possessing the toys. Their play could have a correctional and therapeutic function in a secure environment of a restricted place where the child feels protected and the child's behaviour is not assessed (Milenski, 2009).

The scientific journals like Problems of Psychology in the 21st Century are the result of the efforts and the co-operative work of the authors, the editors, the reviewers and the readers in multicultural environment. Its aim is to promote scientific knowledge that could improve mutual understanding and coping strategies in everyday life situations.

\section{References}

CHARIS (2012). Managing the Multicultural Environment. Winner of the "Excellence through Diversity" Award. http://www.chariscorp.com/mime.asp

Henderson, B. B., Marx, M. H., \& Kim, Y. C. (1999). Academic Interests and Perceived Competence in American, Japanese, and Korean Children. Journal of Cross-Cultural Psychology, 30 (1), 32-50.

Hofstede, H. (2001). Kulturi Iorganizatzii: softuer na uma [Cultures and organizations: mind softwere]. Sofia: Klasika and stil.

Konečná, Z. (2006). Cross-Culture Management: Worker in a Multicultural Environment. Vadyba / Management, 3-4 (12-13), 58-64.

Mesmer-Magnus, J. R., DeChurch, L. A., \& Wax, A. (2012). Moving emotional labor beyond surface and deep acting: A discordance-congruence perspective. Organizational Psychology Review, 2 (1), 6-53.

Milenski, I. (2009). Osobenosti na igrata pri detza vazpitavani bez roditeli [Peculiarities of the play of the childrens raised without their parents]. Psihologia jurnal, 6 (1-55), 14-17.

Mizova, B. (2004). Ubejdavashtata verbalna komunikatzia [Persuasive verbal communication]. Insight, 4, 35-37.

Petrov, D. (2006). Postdinamikata [Post-dynamic]. Insight, 3, 55-56.

Recchia, S., \& Steffgen, G. (2007). Riskfactors of teacher burnout. Paper presented at Xth European Congress in Prague, Czech Republic, in July 2007.

Strube, M. J. (1981). Meta-Analysis and Cross-Cultural Comparison : Sex Differences in Child Competitiveness. Journal of Cross-Cultural Psychology, 12 (1), 3-20.

Totzeva, Y. (2012). Pedagogicheski tehnologii za rabota v multikulturna sreda. Avtorska programa [Pedagogical technologies for work in multicultural environment. Author's syllabus]. Association "Professional forum for education", Retrieved on July 2012, from http://ytotseva.blogspot.com/

Received: January 31, 2013

Accepted: February 27, 2013

Stanislava Stoyanova

PhD., Associate Professor, South-West University "Neofit Rilski", 66 Ivan Michailov Street,

2700 Blagoevgrad, Bulgaria.

E-mail: avka@abv.bg

Website: http://acad.swu.bg/cvp.php?uid=avka 